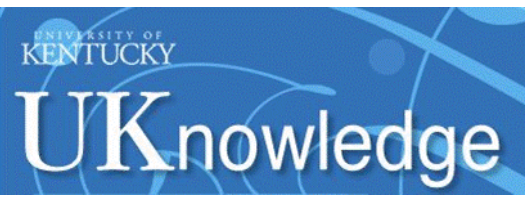

University of Kentucky

UKnowledge

Winter 2018

\title{
Book Review: Sustainable Thinking: Ensuring Your Library's Future in an Uncertain World
}

Jennifer A. Bartlett

University of Kentucky, jen.bartlett@uky.edu

Follow this and additional works at: https://uknowledge.uky.edu/libraries_facpub

Part of the Library and Information Science Commons

Click here to let us know how access to this document benefits you.

\section{Repository Citation}

Bartlett, Jennifer A., "Book Review: Sustainable Thinking: Ensuring Your Library's Future in an Uncertain World" (2018). Library Faculty and Staff Publications. 300.

https://uknowledge.uky.edu/libraries_facpub/300

This Review is brought to you for free and open access by the University of Kentucky Libraries at UKnowledge. It has been accepted for inclusion in Library Faculty and Staff Publications by an authorized administrator of UKnowledge. For more information, please contact UKnowledge@lsv.uky.edu. 
Book Review: Sustainable Thinking: Ensuring Your Library's Future in an Uncertain World

Digital Object Identifier (DOI)

https://doi.org/10.5860/rusq.58.2.6939

Notes/Citation Information

Published in Reference \& User Services Quarterly, v. 58, issue 2, p. 122-123.

(c) 2019 RUSA

The copyright holder has granted the permission for posting the article here. 


\section{SOURCES}

Sustainable Thinking: Ensuring Your Library's Future in an Uncertain World. By Rebekkah Smith Aldrich. Chicago: ALA, 2018. 194 p. Paper \$49.99 (ISBN-13: 978-0-83891688-9).

Although the concept of "sustainability" has many possible meanings, its connection to environmental issues is perhaps the most familiar. Thus, a reader coming across Rebekkah Smith Aldrich's new book might assume that it is primarily about how libraries can best demonstrate stewardship of environmental resources. While this is certainly one important piece of the discussion, Sustainable Thinking has a much larger goal: advocating the capacity of libraries to build communities, whether it be through environmental, financial, leadership, political, or other initiatives.

As a long-time advocate for libraries and sustainability, Aldrich has a wealth of experience in library advocacy and communicates her message well. This book is comprised of several easy-to-read and brief chapters (no more than five pages), with a thought-provoking exercise at the end of each reading. Section One, "Situation Report," sets the stage: use of public libraries is down, although people still have generally favorable opinions of them. It's necessary for librarians to be aware of the many disruptions-political, economic, technological, environmental, and societal-surrounding them and their institutions to develop effective strategies for survival.

Section Two, "The Strategy," outlines ways that libraries can inventory themselves, their communities, and their values. Particularly interesting in this section is Aldrich's construct of the Three E's of Sustainable Libraries: Empower, Engage, and Energize, which serves as a focal point around which libraries can self-inventory their connection to their communities. Section Three, "The Tactics," builds on the 
preceding discussions of environment and mission to help libraries develop their own action plan to connect with and build their communities.

Aldrich has an engaging, conversational writing style, and packs quite a lot of useful information into a few pages. The worksheets, checklists, questions for discussion, and other supplementary material are useful exercises for individual and group discussion. Sustainable Thinking is a thoughtful, well-written workbook for anyone interested in library sustainability on an individual and institutional level._Jennifer A. Bartlett, Interim Associate Dean of Teaching, Learning, \& Research, University of Kentucky Libraries, Lexington, Kentucky 